\title{
Dinuclear Copper(I) Thiodiacetate Complex-Mediated Expeditious Synthesis of the Chlorine-Containing Cyclen-Cored 36-Glucose-Coated Glycodendrimer
}

\author{
Anand K. Agrahari, ${ }^{1}$ Sunil Kumar, ${ }^{1}$ Anindra Sharma ${ }^{D},{ }^{2}$ and Vinod K. Tiwari ${ }^{1}{ }^{1}$ \\ ${ }^{1}$ Department of Chemistry, Institute of Science, Banaras Hindu University, Varanasi 221005, India \\ ${ }^{2}$ Department of Chemistry, A.P.S.M. College-Barauni, LNM University, Darbhanga, India \\ Correspondence should be addressed to Vinod K. Tiwari; tiwari_chem@yahoo.co.in
}

Received 20 September 2021; Revised 8 October 2021; Accepted 15 October 2021; Published 27 October 2021

Academic Editor: $\mathrm{Hu} \mathrm{Li}$

Copyright (c) 2021 Anand K. Agrahari et al. This is an open access article distributed under the Creative Commons Attribution License, which permits unrestricted use, distribution, and reproduction in any medium, provided the original work is properly cited.

\begin{abstract}
High-sugar-tethered glycodendrimers are a remarkable tool in glycobiology for the investigation of carbohydrate-protein interaction using its multivalency property. An enthralling double-stage convergent synthetic approach was selected to build a novel class of chlorine-containing glucose-coated dendrimers using an efficient click catalyst 'dinuclear copper(I) thiodiacetate complex.' In this context, cyclen core was developed through a divergent approach, while the glucodendron was developed via a convergent approach independently. Both azide-alkyne partners were coupled through a modular copper azide-alkyne cycloaddition (CuAAC) strategy to afford a high yield of the desired 36-glucose-coated glycodendrimer. The synthesized glycodendrimer has been elucidated by NMR, gel permeation chromatography (GPC), and IR spectral analysis.
\end{abstract}

\section{Introduction}

Glycodendrimer chemistry is an increasingly important area to overcome the low affinity and specificity of monosaccharide ligands mainly because of its multivalency effect [1-3]. As we know, multivalent carbohydrate-protein interaction regulates numerous biological processes such as cell recognition, cellular adhesion, pathogen invasion, and fertilization [4-8]. The suffice structural diversity of carbohydrates along with their remarkable features such as hydrophilicity, biocompatibility, less toxicity, and superior ADME (absorption, distribution, metabolism, and excretion) properties encouraged the scientist towards the construction of sugar-tethered dendrimers, i.e., glycodendrimers $[1,9,10]$. Glycodendrimers, because of several notable features such as their high number of sugar appendages at the periphery, enhanced monodispersity, and, moreover, the possibility to organize their well-defined size, have been captivated over the other class of multivalent glycoclusters [11-16]. Cyclen core is well investigated for its wide application in the field of chemical biology and biomedicine [17]. In recent years, cyclen and related macrocyclic polyamines have been greatly explored as a promising vehicle of radio nuclides in radio immunotherapy (RIT), single-photon emission computed tomography (SPECT), and positron [18]. The easy $N$-alkylation of cyclens facilitates significant alteration in the macrocycles for the development of promising hypercore of wide applications [19-21]. Therefore, several chemical ligation tools have been reported for the successful synthesis of glycodendrimer [22-29].

Among the other applied protocols including chemical ligation, Michael addition, and acid-amine coupling, copper(I)-catalyzed azide-alkyne cycloaddition (CuAAC) reaction, i.e., click chemistry, is one of the most reliable, adaptable, efficient, high-yielding, and proficient tool for an easy access of regioselective glycohybrids, glycoconjugates, and neoglycoconjugates $[1,27,30]$. In most of the cases, clicking of azides and alkynes was executed simply by using the $\mathrm{CuSO}_{4} / \mathrm{NaAsc}$ catalytic system in the aqueous condition, which is especially favorable in terms of yields and 
regioselectivity [30]. However, it has few shortcomings as it requires higher quantity and prolonged time, has insufficient stability, and has the reducing nature of NaAsc that may also facilitate some other unwanted reactions with proteins in biological systems [31]. Thus, there is an increased demand of suitable click catalysts for efficient CuAAC coupling. Towards this end, a number of promising such catalysts such as mono- and dinuclear heteroleptic $\mathrm{Cu}(\mathrm{I})$ dithio- $\mathrm{PPh} 3$ complexes [32], di- and mononuclear heteroleptic $\mathrm{Cu}(\mathrm{I})$ dixanthate/xanthate-phosphine complexes [33], heteroleptic $\left[\mathrm{Cu}\left(\mathrm{PPh}_{3}\right)_{2}(\beta\right.$-oxodithioester $\left.)\right]$ complexes [34], thiocarboxylate complexes, and cubane-based hydrosulfide complexes of $\mathrm{Cu}(\mathrm{I})$ [35] were displayed efficient catalytic activities for the click conjugation with carbohydrates. Among all, a highly stable $\mathrm{Cu}(\mathrm{I})$ catalyst $\left[\left(\mathrm{PPh}_{3}\right)_{2} \mathrm{Cu}(\mu\right.$-tda $)$ $\left.\mathrm{Cu}\left(\mathrm{PPh}_{3}\right)_{2}\right] \cdot 6 \mathrm{H}_{2} \mathrm{O}$ with significant catalytic activity has been copiously exploited for the thriving construction of regioselective 1,4-disubstituted dendritic architectures [36].

As reported in the literature, the chlorine atoms occupy a special position in a variety of potent natural products such as the antibiotics vancomycin, clindamycin, chloramphenicol, and griseofulvin [37, 38]. Thus, this inclusion of chlorine atoms into one or more definite loci of a biologically active scaffold may enhance the inherent biological activity [39]. The chlorinated compounds might increase the lipophilicity of the whole molecule towards lipophilic domains of a protein which prompts an increased local concentration of the said compound near a biological target site. Until now, only a few literature reports are available to develop highfunctional chlorine-containing glycodendrimers [40]. The notable lead of such type of glycocluster is the amplified functional group concentration in the reduced generation which unfolds a key domain for the sugar-lectin interaction [41, 42]. Therefore, we envisaged constructing 36-glucosecoated chlorine-containing dendrimers of $G_{1}$ generation (Figure 1) using the copper catalyst 'dinuclear copper(I) thiodiacetate complex' in standard click ambience.

\section{Experimental}

2.1. General Experimental Procedure for the Cu(I)-Catalyzed Click Reaction. Polypropargylated terminal alkyne and its counterpart organic azide and catalyst $9(0.02$ equiv. or $2 \mathrm{~mol}$ $\%$ per propargyl) were stirred in dry $\mathrm{CH}_{2} \mathrm{Cl}_{2}$ for $3 \mathrm{~h}$. The completion of the reaction was monitored by TLC; upon completion of the reaction, the solvent was removed under reduced pressure to obtain the crude product. The resulting crude mass was purified using flash column chromatography to afford the targeted glycoconjugates.

2.2. Synthetic Procedure of Methyl 3,4,5-Tris (Hydroxyl) Benzoate (2) [29]. 3,4,5-Tris (hydroxyl) benzoic acid 1 (5.0 g, $32.4 \mathrm{mmol})$ was dissolved in dry methanol $(80 \mathrm{~mL})$; thereafter, the catalytic amount of conc. $\mathrm{H}_{2} \mathrm{SO}_{4}(1.0 \mathrm{~mL})$ was added dropwise in the cold condition. Furthermore, the reaction was set to reflux for $5 \mathrm{~h}$. After the consumption of the starting material on TLC, the resulting reaction mixture was condensed under in vacuo followed by extraction. Thus, ethyl acetate $(100 \mathrm{~mL})$ was added to the obtained crude mass and washed with $\mathrm{NaHCO}_{3}$ solution $(2 \times 50 \mathrm{~mL})$, dried over anhydrous $\mathrm{Na}_{2} \mathrm{SO}_{4}$, filtered, and again evaporated to furnish the targeted scaffold 2 in good yield. The physical data (NMR) of compound 2 were closely matched with the reported literature.

\subsection{Synthetic Procedure of Methyl 3,4,5-Tris (Propargyloxy)} Benzoate (3) [29]. The said compound was synthesized as reported in the literature. Spectroscopic data were matched with the earlier reported literature.

\subsection{Synthetic Procedure for 3,4,5-Tris (Propargyloxy) Phenyl} Methanol (4) [40]. To a stirred solution of anhydrous THF ( $40 \mathrm{~mL}), \mathrm{LiAlH}_{4}(0.45 \mathrm{~g}, 11.8 \mathrm{mmol}, 1.2$ equiv) was added at $0^{\circ} \mathrm{C}$ followed by portion-wise addition of ester $3(3.0 \mathrm{~g}$, $10.05 \mathrm{mmol}$ ) in a period of $15 \mathrm{~min}$ maintaining the said temperature. Then, the reaction was set to stir for $6 \mathrm{~h}$ at room temperature until the completion of the reaction (monitored by TLC). The resulting reaction mixture was quenched by $5 \%$ aq. $\mathrm{NaOH}$, and then the resulting precipitate was filtered out; the resulting filtrate was extracted with ethyl acetate and washed with water $(2 \times 20 \mathrm{~mL})$ followed by brine wash. The obtained organic layer was evaporated under reduced pressure, and the resulting crude mass was loaded to column chromatography to furnish the targeted compound 4 . Spectroscopic data were matched with the earlier reported literature.

\subsection{Synthesis of $\mathrm{AB}_{3}$ Dendritic Monomer (5) [40].} 3,4,5-Tris (propargyloxy) phenyl methanol 3 (2.0 g, $7.39 \mathrm{mmol}$ ) was taken in a round bottom flask, and sulfuryl chloride ( $7.17 \mathrm{~mL}, 12.0$ equiv) was added and stirred for 30 minutes at $\mathrm{rt}$. Thereafter, the completion of the reaction was monitored by TLC, the reaction mixture was diluted, was then neutralized with $20 \%$ aq. $\mathrm{NaOH}$ at $0^{\circ} \mathrm{C}$, and was extracted with ethyl acetate $(50 \mathrm{~mL})$, dried over anhydrous $\mathrm{Na}_{2} \mathrm{SO}_{4}$, and filtered, and the solvent was evaporated in vacuo $\left(<55^{\circ} \mathrm{C}\right)$. The obtained residue was refined by flash column chromatography $\left(\mathrm{SiO}_{2}\right)$ to furnish the desired compound 5. Yield (2.06 g, 78\%); $R_{f}=0.5(15 \% \mathrm{EtOAc} / n$ hexane); ${ }^{1} \mathrm{H}-\mathrm{NMR}\left(500 \mathrm{MHz}, \mathrm{CDCl}_{3}\right): \delta=4.87(\mathrm{~s}, 4 \mathrm{H}$, $\left.2 \times-\mathrm{OCH}_{2}\right), 4.81\left(\mathrm{~s}, 4 \mathrm{H}, 2 \times-\mathrm{CH}_{2}\right), 2.57-2.56(\mathrm{~m}, 1 \mathrm{H}$, acetylenic- $\mathrm{H}), 2.54-2.53(\mathrm{~m}, 2 \mathrm{H}, 2 \times$ acetylenic- $\mathrm{H}) ;{ }^{13} \mathrm{C}$ NMR $\left(125 \mathrm{MHz}, \mathrm{CDCl}_{3}\right): \delta=147.0,146.3,129.9,126.3$, $77.86,77.83,76.6,76.4,61.2,61.0$, and $41.1 \mathrm{ppm}$.

2.6. Synthesis of 12-Alkynyl-Functionalized Hypercore (7) [40]. 1,3-Dichloro-2-(chloromethyl)-4,5,6-tris (propargyloxy) benzene 5 ( $187 \mathrm{mg}, 0.522 \mathrm{mmol}, 4.5$ equiv) reacted with macrocycle cyclen unit 6 (20 mg, $0.116 \mathrm{mmol}, 1.0$ equiv) under the mixture of aqueous $1 \mathrm{M} \mathrm{NaOH}(15 \mathrm{~mL})$ and $\mathrm{CH}_{3} \mathrm{CN}(15 \mathrm{~mL})$. The reaction was allowed to stir for $12 \mathrm{~h}$ at room temperature (the progress of the reaction was monitored by TLC), and then it was extracted with ethyl acetate $(2 \times 20 \mathrm{~mL})$. The organic layer was collected, dried over $\mathrm{Na}_{2} \mathrm{SO}_{4}$, and filtered, and the solvent was evaporated under 


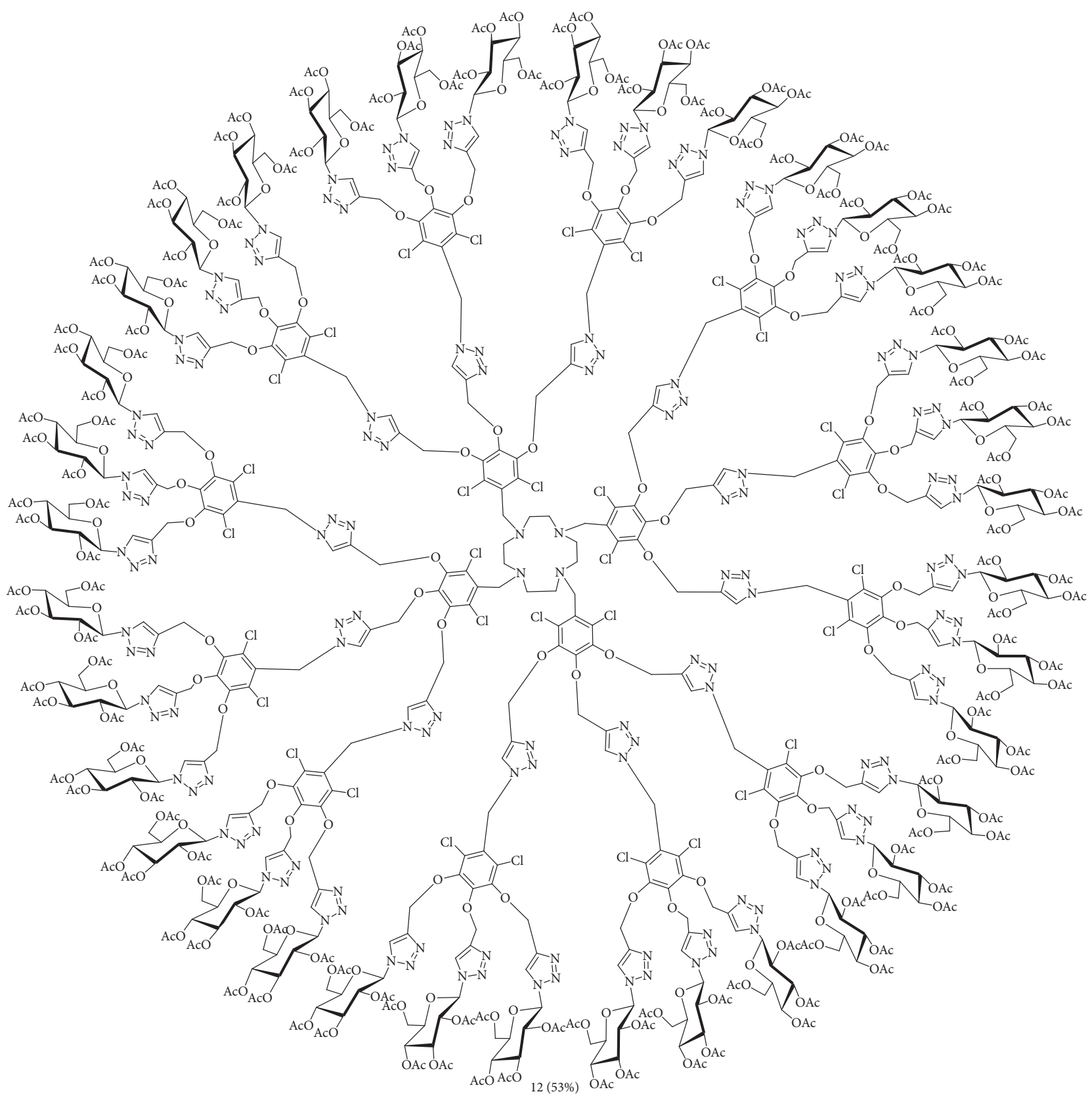

FIGURE 1: Structure of 36-glucose-coated chlorine-containing cyclen-cored glycodendrimer 12.

in vacuo $\left(<55^{\circ} \mathrm{C}\right)$. The resulted residue was loaded to column chromatography to furnish the desired hypercore 7 in good yield. Yield (111 mg, 66\%); $R_{f}=0.3$ (25\% EtOAc/ $n$-hexane); ${ }^{1} \mathrm{H}-\mathrm{NMR}\left(500 \mathrm{MHz}, \mathrm{CDCl}_{3}\right): \delta=4.83(\mathrm{~d}, J=2.0 \mathrm{~Hz}, 8 \mathrm{H}$, $\left.4 \times-\mathrm{NCH}_{2} \mathrm{Ar}\right), 4.78-4.77(\mathrm{~m}, 16 \mathrm{H}$, cyclen-H), $3.64(\mathrm{~s}, 8 \mathrm{H}$, $\left.\left.4 \times-\mathrm{OCH}_{2}\right), 2.77\left(\mathrm{~s}, 16 \mathrm{H}, 8 \times-\mathrm{OCH}_{2}\right)\right), 2.51-2.49(\mathrm{~m}, 12 \mathrm{H}$, acetylenic-H); ${ }^{13} \mathrm{C}-\mathrm{NMR} \quad\left(125 \mathrm{MHz}, \quad \mathrm{CDCl}_{3}\right): \delta=146.5$, $145.0,132.1,127.1,78.2,78.1,76.3,76.2,61.1,60.8,54.9$, and $50.7 \mathrm{ppm}$.

2.7. Synthetic Protocol of 2,3,4,6-Tetra-O-acetyl- $\beta$-D-glucopyranosyl Azide (8) [16]. Compound 8 was synthesized as reported in the literature, and the spectral data were well elucidated.
2.8. Synthesis of Catalyst $\left[\left(\mathrm{PPh}_{3}\right)_{2} \mathrm{Cu}(\mu-t d a) \mathrm{Cu}\left(\mathrm{PPh}_{3}\right)_{2}\right] \cdot 6 \mathrm{H}_{2} \mathrm{O}$ (9) [36]. The catalyst was synthesized as earlier reported in the literature, and spectral data were closely matched with the reference sample.

2.9. Synthesis of the Chlorine-Functionalized Glucodendron (10). Compound 1,3-dichloro-2-(chloromethyl)-4,5,6-tris (propargyloxy) benzene $5(0.1 \mathrm{~g}, 0.279 \mathrm{mmol})$ reacted with 2,3,4,6-tetra-O-acetyl- $\beta$-D-glucopyranosyl azide $8(417 \mathrm{mg}$, $1.11 \mathrm{mmol}, 4.0$ equiv.) using catalyst 9 ( $24.6 \mathrm{mg}, 0.06$ equiv.) under dry $\mathrm{CH}_{2} \mathrm{Cl}_{2}$ solvent according to the general procedure. The obtained crude mass was subjected to flash column chromatography $\left(\mathrm{SiO}_{2}\right)$ to form chlorine-functionalized glycoconjugate 10 in good yield. Yield (346 mg, 84\%) 
$R_{f}=0.4$ (50\% ethyl acetate $/ n$-hexane); ${ }^{1} \mathrm{H}-\mathrm{NMR}(500 \mathrm{MHz}$, $\left.\mathrm{CDCl}_{3}\right): \quad \delta=8.34 \quad(\mathrm{~s}, 1 \mathrm{H}, \quad$ triazolyl-H), $8.21 \quad(\mathrm{~s}, \quad 2 \mathrm{H}$, $2 \times$ triazolyl-H), $6.07\left(\mathrm{~d}, J=9.5 \mathrm{~Hz}, 2 \mathrm{H}, \mathrm{H}_{1}\right), 5.97$ (d, $\left.J=9.5 \mathrm{~Hz}, 1 \mathrm{H}, \mathrm{H}_{1}\right), 5.59-5.52\left(\mathrm{~m}, 3 \mathrm{H}, \mathrm{H}_{3}\right), 5.44-5.27(\mathrm{~m}$, $\left.10 \mathrm{H}, \mathrm{H}_{2},-\mathrm{CH}_{2} \mathrm{Ar}\right), 4.69-4.68\left(\mathrm{~m}, 2 \mathrm{H}, \mathrm{H}_{2}, \mathrm{H}_{4}\right), 4.27-4.24(\mathrm{~m}$, $\left.3 \mathrm{H}, \mathrm{H}_{4}, \mathrm{H}_{6 \mathrm{a}}\right), 4.15-4.04\left(\mathrm{~m}, 8 \mathrm{H}, \mathrm{H}_{5}, \mathrm{H}_{6}\right), 2.05(\mathrm{~s}, 8 \mathrm{H}$, $\left.-\mathrm{COCH}_{3}\right), 2.01-2.0\left(\mathrm{~m}, 16 \mathrm{H}, 8 \times-\mathrm{COCH}_{3}\right), 1.92(\mathrm{~s}, 5 \mathrm{H}$, $\left.-\mathrm{COCH}_{3}\right), \quad 1.84-1.81\left(\mathrm{~m}, \quad 7 \mathrm{H}, \quad-\mathrm{COCH}_{3}\right) ;{ }^{13} \mathrm{C}-\mathrm{NMR}$ $\left(125 \mathrm{MHz}, \mathrm{CDCl}_{3}\right): \delta=170.5,170.4,169.99,169.94,169.5$, $169.4,168.9,168.7,147.0,146.9,143.9,143.4,130.0,126.1$, $122.8,122.7,85.6,85.5,75.0,74.8,72.8,72.7,70.2,70.1,67.7$, $67.6,66.9,65.4,61.6,61.4,41.3,20.59,20.54,20.4,20.1$, and $20.0 \mathrm{ppm}$. IR (KBr): $\nu_{\max } 3473.73,2958.25,1755.58$, $1434.9 \mathrm{~cm}^{-1}$. HRMS: $\mathrm{m} / \mathrm{z}=\mathrm{C}_{58} \mathrm{H}_{69} \mathrm{Cl}_{3} \mathrm{~N}_{9} \mathrm{O}_{30}{ }^{+}$; calculated $=1476.3211$; found $=1476.3215(\mathrm{M}+\mathrm{H})^{+}$.

2.10. Synthesis of the Azide-Functionalized Glucodendron (11). Glycoconjugated dendron $10(0.3 \mathrm{~g}, 0.203 \mathrm{mmol})$ was dissolved in DMF, then sodium azide $(52 \mathrm{mg}, 0.812 \mathrm{mmol}$, 4.0 equiv.) was administered in argon ambient, and the reaction was continuously stirred for $12 \mathrm{~h}$ at $70^{\circ} \mathrm{C}$. The reaction mixture was evaporated under reduced pressure, and the obtained crude mass was extracted with ethyl acetate $(2 \times 20 \mathrm{~mL})$, cleaned with brine solution $(2 \times 15 \mathrm{~mL})$, and dried over anhydrous sodium sulphate. The organics were collected and concentrated; the resulting residue was loaded to column chromatography to furnish the targeted azidefunctionalized dendritic wedge 11 in excellent yield. Yield (295 mg, 98\%) $R_{f}=0.4$ (55\% ethyl acetate $/ n$-hexane); ${ }^{1} \mathrm{H}$ NMR $\left(500 \mathrm{MHz}, \mathrm{CDCl}_{3}\right): \delta 8.30(\mathrm{~s}, 1 \mathrm{H}$, triazolyl-H), $8.22(\mathrm{~s}$, $2 \mathrm{H}$, triazolyl-H), $6.07\left(\mathrm{~d}, J=9.5 \mathrm{~Hz}, 2 \mathrm{H}, \mathrm{H}_{1}\right), 5.97$ (d, $\left.J=9.5 \mathrm{~Hz}, 1 \mathrm{H}, \mathrm{H}_{1}\right), 5.60-5.53\left(\mathrm{~m}, 3 \mathrm{H}, \mathrm{H}_{3}\right), 5.46-5.30(\mathrm{~m}$, $\left.11 \mathrm{H}, \mathrm{H}_{3},-\mathrm{CH}_{2} \mathrm{Ar}\right), 4.53-4.47\left(\mathrm{~m}, 2 \mathrm{H}, \mathrm{H}_{2}\right), 4.29-4.26(\mathrm{~m}, 3 \mathrm{H}$, $\left.\mathrm{H}_{2}, \mathrm{H}_{4}\right), 4.16-4.09$ (m, 7H, H$\left., \mathrm{H}_{5}, \mathrm{H}_{6}\right), 2.077-2.074(\mathrm{~m}, 9 \mathrm{H}$, $\left.3 \times-\mathrm{COCH}_{3}\right), 2.03-2.02\left(\mathrm{~m}, 12 \mathrm{H}, 4 \times-\mathrm{COCH}_{3}\right), 1.95(\mathrm{~s}, 6 \mathrm{H}$, $\left.2 \times-\mathrm{COCH}_{3}\right), 1.86\left(\mathrm{~s}, 3 \mathrm{H},-\mathrm{COCH}_{3}\right), 1.83(\mathrm{~s}, 6 \mathrm{H}$, $\left.2 \times-\mathrm{COCH}_{3}\right) ;{ }^{13} \mathrm{C}-\mathrm{NMR}\left(125 \mathrm{MHz}, \mathrm{CDCl}_{3}\right): \delta 170.5,170.4$, $170.0,169.9,169.5,169.4,168.9,168.7,146.97,146.93,143.9$, $143.4,128.1,126.3,122.8,122.7,85.6,85.5,75.0,74.8,72.9$, $72.7,70.2,70.1,67.7,67.5,66.9,65.4,61.6,61.4,49.6,20.6$, 20.56, 20.50, 20.14, and $20.11 \mathrm{ppm}$. IR (KBr): $\nu_{\max } 3448.33$, 2966.6, 2104.96, 1755.21, $1647.97 \mathrm{~cm}^{-1}$. HRMS: $\mathrm{m} / \mathrm{z}=\mathrm{C}_{58}$ $\mathrm{H}_{69} \mathrm{Cl}_{2} \mathrm{~N}_{12} \mathrm{O}_{30}{ }^{+}$; calculated $=1483.3615 ;$ found $=1483.3607$ $(\mathrm{M}+\mathrm{H})^{+}$.

2.11. Synthetic Procedure for Chlorine-Containing 36-GlucoseCoated Glycodendrimer (12). Glycoconjugate dendron 11 (229 mg, $154 \mu \mathrm{mol}, 15.0$ equiv.) was grafted over hypercore $37(20 \mathrm{mg}, 10.2 \mu \mathrm{mol})$ using catalyst 9 ( $5 \mathrm{mg}, 0.24$ equiv.) according to the general procedure for the $\mathrm{Cu}(\mathrm{I})$-catalyzed click reaction as described earlier to generate glycodendrimer 12 in moderate yield. Yield (53\%); $R_{f}=0.50(10 \%$ $\left.\mathrm{MeOH} / \mathrm{CH}_{2} \mathrm{Cl}_{2}\right) ;{ }^{1} \mathrm{H}-\mathrm{NMR}\left(500 \mathrm{MHz}, \mathrm{CDCl}_{3}\right): \delta=8.39-8.21$ (m, $40 \mathrm{H}$, triazolyl- $\mathrm{H}), 8.02-8.00(8 \mathrm{H}$, triazolyl- $\mathrm{H}), 6.12-5.97$ (m, 24H), 5.66-5.57 (m, 36H), 5.42-5.29 (m, 84H), 5.09 (d, $J=4.0 \mathrm{~Hz}, 24 \mathrm{H}), 4.89-4.71(\mathrm{~m}, 84 \mathrm{H}), 4.29-4.10(\mathrm{~m}, 72 \mathrm{H})$, 3.89-3.82 (m, 48H), $3.57(\mathrm{~s}, 8 \mathrm{H}), 2.63\left(\mathrm{~s}, 16 \mathrm{H},-\mathrm{COCH}_{3}\right)$, 2.08-1.97 (m, 216H, $\left.-\mathrm{COCH}_{3}\right), 1.91-1.86(\mathrm{~m}, 216 \mathrm{H}$,
$\left.-\mathrm{COCH}_{3}\right) ;{ }^{13} \mathrm{C}-\mathrm{NMR}\left(125 \mathrm{MHz}, \mathrm{CDCl}_{3}\right): \delta=170.5,170.0$, $169.6,169.4,168.9,168.7,147.3,147.1,146.9,146.6,146.4$, $143.7,143.2,139.1,137.0,128.2,127.2,127.1,127.0,126.5$, $126.4,124.7,123.4,123.2,123.0,122.8,114.0,103.7,85.6$, $75.0,74.8,72.9,72.7,70.1,67.7,67.6,66.8,65.9,65.0,61.6$, $61.3,61.2,60.9,50.3,49.5,48.4,20.6,20.5$, and $20.1 \mathrm{ppm}$. IR $(\mathrm{KBr}): \quad v_{\max } \quad 3444.07, \quad 2924.30, \quad 2853.33, \quad 1754.51$, $1638.87 \mathrm{~cm}^{-1}$.

\section{Results and Discussion}

To emphasize the importance of multivalent properties for carbohydrate-lectin interaction, we have designed and developed the cyclen-cored 36 -glucose-coated ( $G_{1}$ generation) glycodendrimer using regioselective triazole-forming CuAAC reaction. An aromatic 'aglycone,' i.e., tris propargyloxy benzoate, was taken as the $\mathrm{AB}_{3}$ monomer for the construction of the dendritic wedge of choice of interest. To build the $G_{1}$-generation cyclen-based glucose-coated dendrimer, a recent double-stage convergent way was embraced which encapsulates both paths, convergent and divergent [43]. Thus, our synthesis of the desired hypercore started with the commercially available gallic acid 1. It was esterified by using $\mathrm{H}_{2} \mathrm{SO}_{4}$ in methanol to form scaffold 2, followed by propargylation, which led to the formation of compound 3 . Subsequently, compound 3 on treatment with lithium aluminum hydride (LAH) in anhydrous THF yielded the corresponding alcohol functionality 4 (Scheme 1). As reported in the literature, chlorine-containing motifs have a family of compounds of promising potential in the medicinal field. Thus, this research encouraged us to develop a novel chlorine-containing glycodendrimer with increased biological importance in the field of pharmaceuticals [44]. Moreover, scaffold 4 was treated with sulfuryl chloride $\left(\mathrm{SO}_{2} \mathrm{Cl}_{2}\right)$ to furnish $\mathrm{AB}_{3}$ monomer 5 (Scheme 1). After the complete elucidation of the developed $\mathrm{AB}_{3}$ monomer 5 , it reacted with cyclen azamacrocycle 6 to construct core 7 (Scheme 1). The obtained hypercore 7 was characterized by its spectral studies.

On the contrary, clickable 2,3,4,6-tetra- $O$-acetyl- $\beta$-Dglucopyranosyl azide 8 was synthesized from the corresponding D-glucose. For this, D-glucose was acetylated using acetic anhydride in the presence of iodine as a catalyst followed by treatment with $\mathrm{HBr}(33 \%)$ in acetic acid [45]. Then, the addition of $\mathrm{NaN}_{3}$ in DMF leads to the formation of azido sugar [16]. After chromatographic refining, the developed azido derivative was well characterized by NMR in the available experimental literature. Once the synthesis of the end groups " $2,3,4,6$-tetra- $O$-acetyl- $\beta$-D-glucopyranosyl azide" and $\mathrm{AB}_{3}$ monomer was accomplished, we next focused towards the regioselective CuAAC click conjugation of azido-appended end group 8 with alkynylated monomer 5. Therefore, we have optimized the dendron synthesis using different catalytic conditions, i.e., entries $1-4$, as depicted in Table 1, in which, first of all, azide 8 was clicked with $\mathrm{AB}_{3}$ monomer 5 under $\mathrm{CuSO}_{4} \cdot 5 \mathrm{H}_{2} \mathrm{O} / \mathrm{NaAsc}$ in $\mathrm{THF} / \mathrm{H}_{2} \mathrm{O}(1: 1)$, reaction was completed in $12 \mathrm{~h}$ at room temperature, and the reaction yield was $80 \%$ (Table 1 , entry 1 ). However, when the reaction was performed by using the stable catalyst dinuclear 

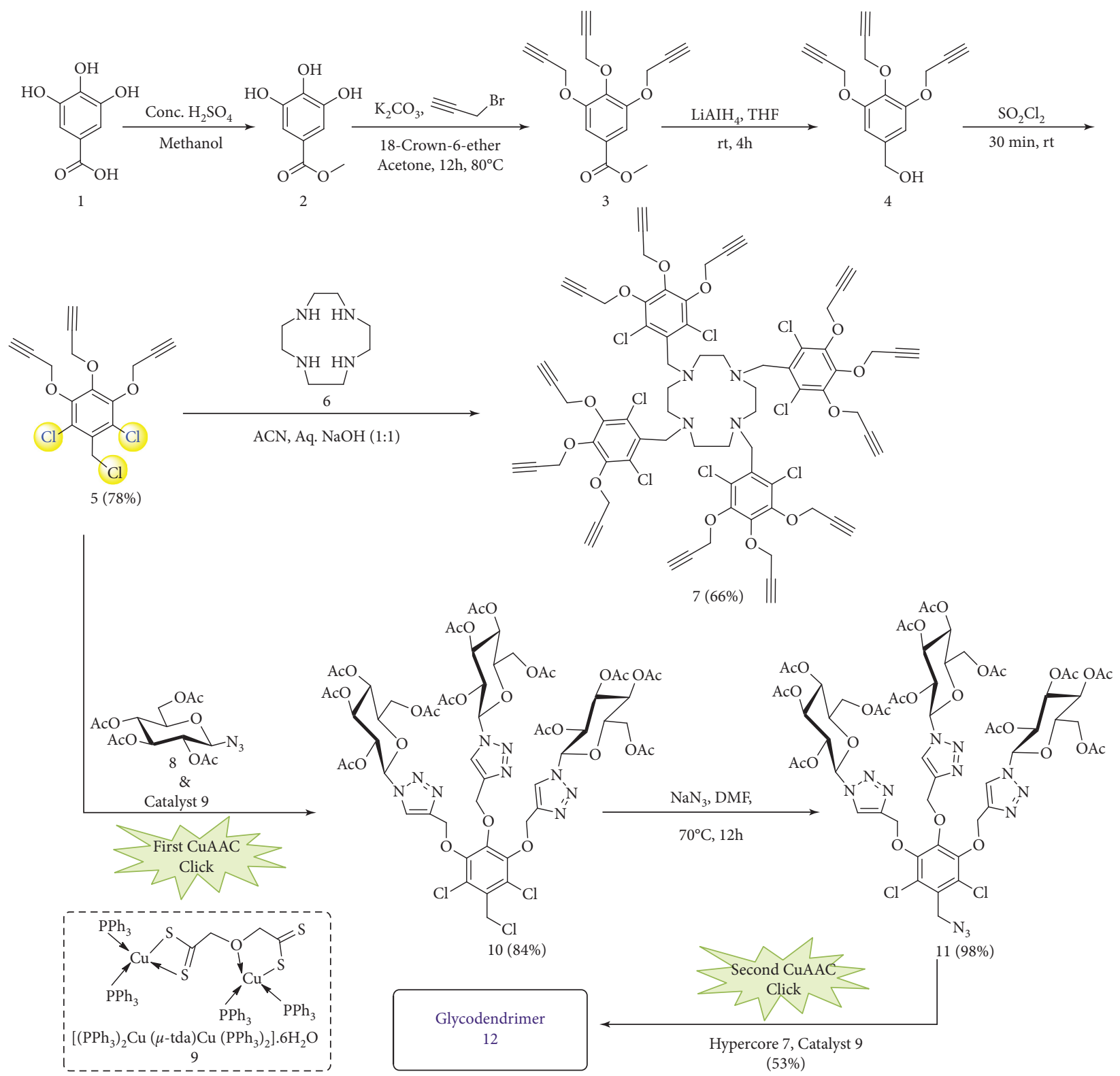

Scheme 1: Synthesis of chlorine-containing $\mathrm{AB}_{3}$ monomer 5, hypercore 7, and azide-functionalized glucodendron 11.

TABLE 1: Optimization of catalysts for the synthesis of the glucodendron.

\begin{tabular}{lcccc}
\hline Entry & Catalytic condition & Temp $\left({ }^{\circ} \mathrm{C}\right)$ & Yield $^{\mathrm{a}}(\%)$ & Time $^{(\mathrm{h})}$ \\
\hline 1 & $\mathrm{CuSO}_{4} \cdot 5 \mathrm{H}_{2} \mathrm{O} / \mathrm{NaAsc}, \mathrm{THF} / \mathrm{H}_{2} \mathrm{O}(1: 1)$ & 55 & 80 & 12 \\
2 & $\mathrm{CuSO}_{4} \cdot 5 \mathrm{H}_{2} \mathrm{O} / \mathrm{NaAsc}, \mathrm{DCM} / \mathrm{H}_{2} \mathrm{O}(1: 1)$ & $\mathrm{rt}$ & 75 & 12 \\
3 & $\mathrm{CuI} / \mathrm{DIPEA}, \mathrm{DCM}^{\mathrm{b}}$ & $\mathrm{rt}$ & 72 & 12 \\
4 & {$\left[\left(\mathrm{PPh}_{3}\right)_{2} \mathrm{Cu}(\mu\right.$-tda $\left.) \mathrm{Cu}\left(\mathrm{PPh}_{3}\right)_{2}\right] \cdot 6 \mathrm{H}_{2} \mathrm{O}(9), \mathrm{DCM}^{\mathrm{b}} / \mathrm{DIPEA}$} & $\mathrm{rt}$ & 84 & 3 \\
\hline
\end{tabular}

${ }^{a}$ Yield reported after column chromatography $\left(\mathrm{SiO}_{2}\right)$. ${ }^{\mathrm{b}}$ Reaction under the anhydrous condition.

$\mathrm{Cu}(\mathrm{I})$ catalyst $\left[\left(\mathrm{PPh}_{3}\right)_{2} \mathrm{Cu}(\mu\right.$-tda $\left.) \mathrm{Cu}\left(\mathrm{PPh}_{3}\right)_{2}\right] \cdot 6 \mathrm{H}_{2} \mathrm{O}(\mathrm{tda}=-$ thiodiacetate anion) 9 [36], the reaction was completed in $3 \mathrm{~h}$, and yield was found to be $84 \%$ (Table 1, entry 4). In this way, the best catalyst, i.e., catalyst 9 , displayed remarkable catalytic advantage in terms of stability, high yield, ligandfree, base-free, and short reaction time for the CuAAC reaction. Therefore, the optimized catalyst 9 was implemented for the development of chlorine-functionalized dendritic wedge 10 along with glycodendrimer 12 .

In order to achieve the first-generation glucodendron, i.e., chlorine-functionalized dendritic wedge $10, \mathrm{AB}_{3}$ monomer 5 was coupled with $2,3,4,6$-tetra- $O$-acetyl- $\beta$-Dglucopyranosyl azide 8 by means of catalyst 9 in anhydrous DCM. Moreover, dendritic unit 10 was altered into 
Chloro-dendron 10

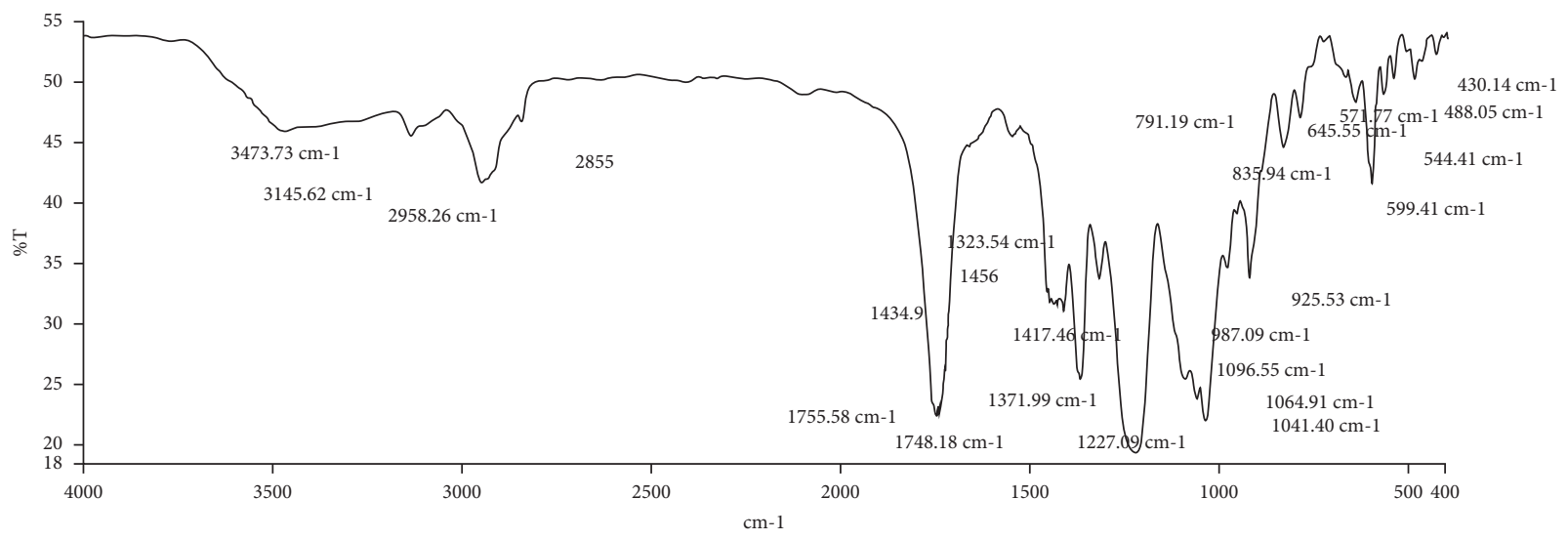

Azido-dendron 11

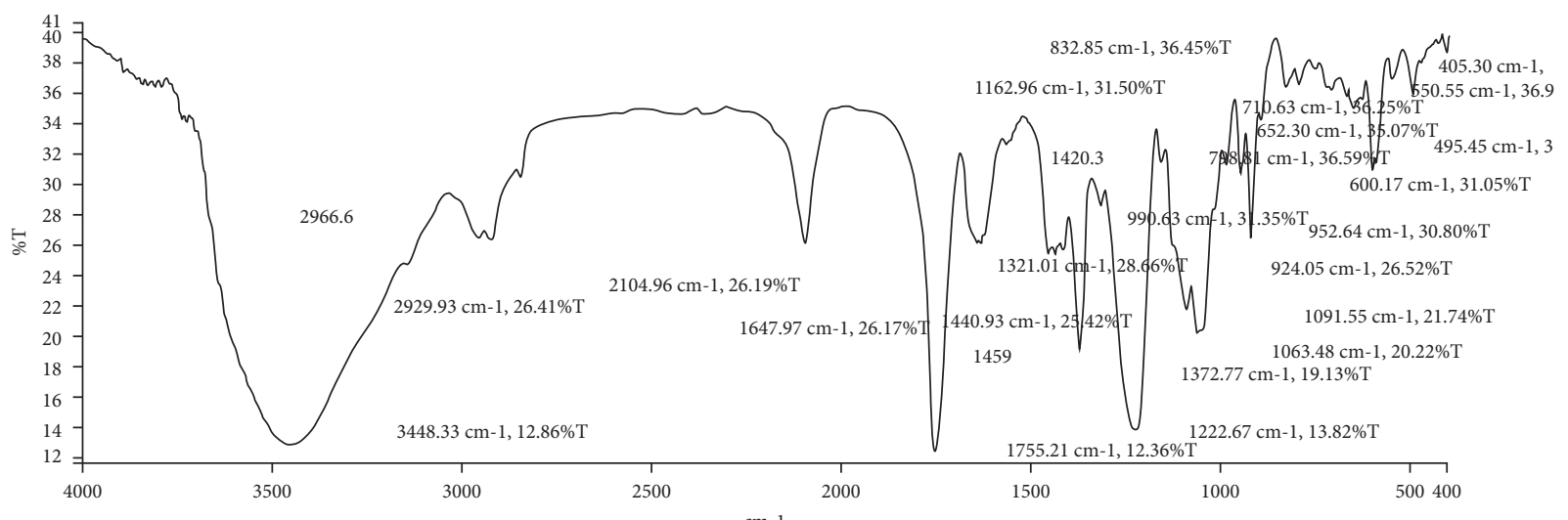

$\mathrm{cm}-1$

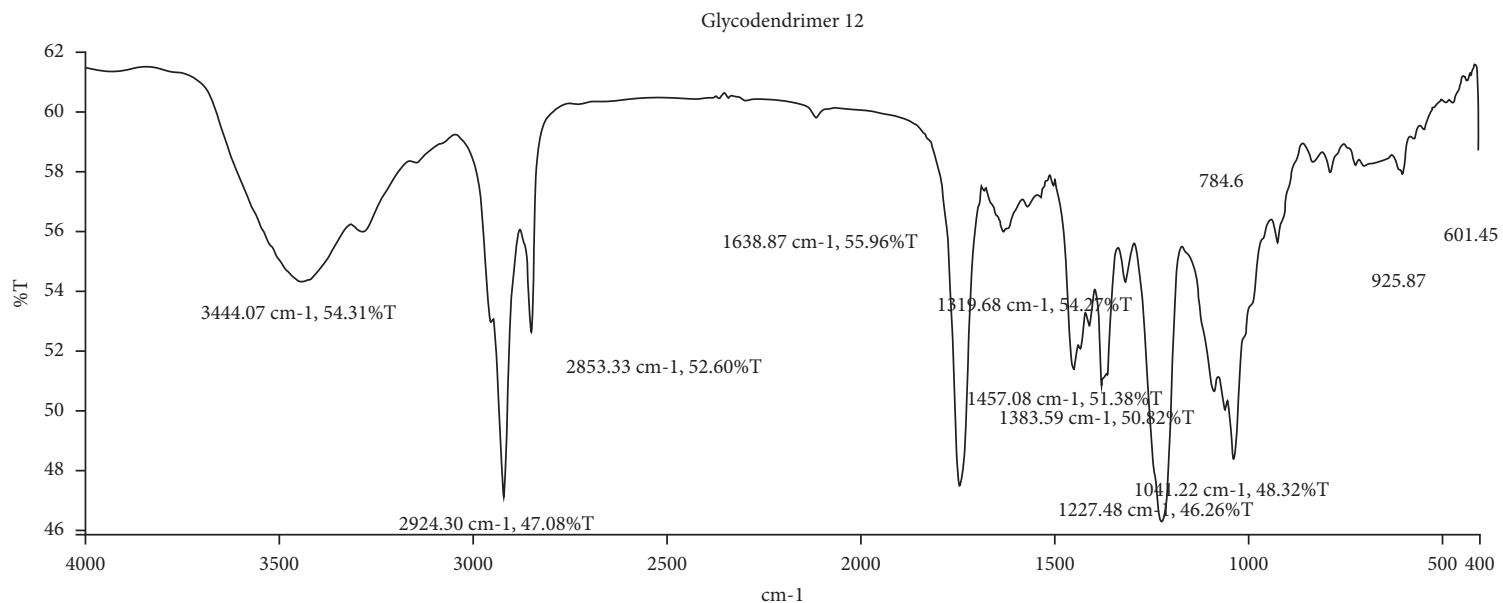

FIGURE 2: IR spectra of chlorine-functionalized dendritic wedge 10, azido-dendron 11, and chlorine-containing glycodendrimer 12.

its required azide-functionalized dendritic moiety 11 . Furthermore, this transformation (from chloro to azido) was confirmed by its IR spectra $\left(2104.96 \mathrm{~cm}^{-1}\right)$ (Figure 2), whereas in ${ }^{13} \mathrm{C}$-NMR, the downfield shifting was noticed during conversion from $-\mathrm{CH}_{2} \mathrm{Cl}(\delta 41.3 \mathrm{ppm})$ to $-\mathrm{CH}_{2} \mathrm{~N}_{3}(\delta 49.6 \mathrm{ppm})$ for scaffold 11 , which clearly indicated the unambiguous formation of azide-functionalized dendron 11 (Figure 3).
Finally, azide-functionalized glucodendron 11 was amalgamated with hypercore 7 using dinuclear copper(I) thiodiacetate catalyst 9 in anhydrous DCM to afford 36-glucosecoated glycodendrimer 12 in moderate yield (Figure 1). For instance, the reaction was completed on TLC, while after column chromatography, only $53 \%$ yield was achieved. Furthermore, the synthesized glycodendrimer was well characterized by its spectroscopic studies. In IR spectra, there was no 

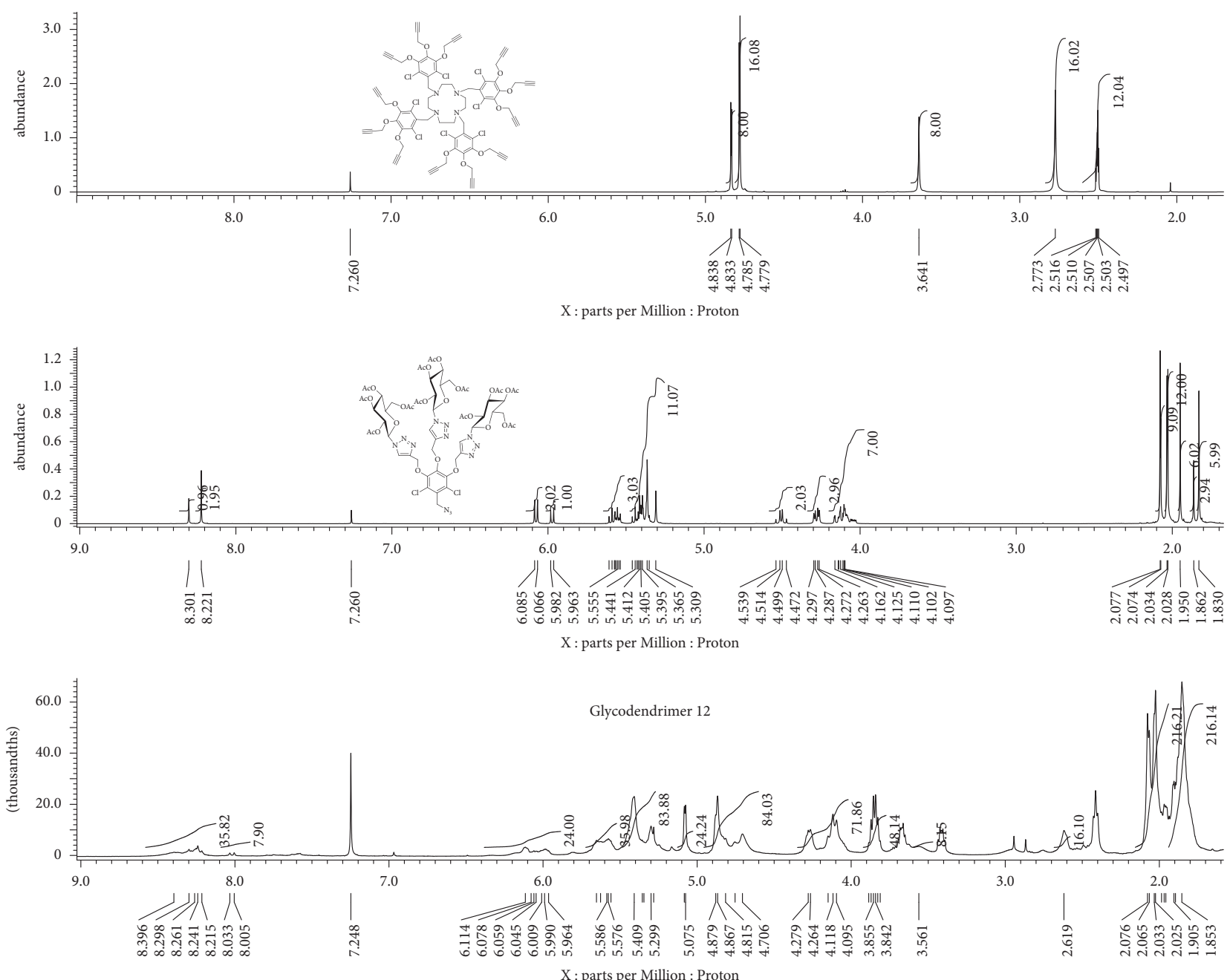

Figure 3: ${ }^{1} \mathrm{H}$-NMR spectra of hypercore 7 , dendritic wedge 11, and chlorine-containing glycodendrimer 12.

vibrating band of azide and alkyne which indicated the complete absence of free alkyne and azide functionality in the constructed glycodendrimers (Figure 2). Furthermore, the developed glycodendrimer was well characterized and studied by its comparative ${ }^{1} \mathrm{H}$-NMR and ${ }^{13} \mathrm{C}-\mathrm{NMR}$ (Figures 3 and 4).

In the ${ }^{1} \mathrm{H}-\mathrm{NMR}$ spectra of compound 12 , the disappearance of acetylenic- $\mathrm{H}$ peak at $2.5 \mathrm{ppm}$ of the core and the appearance of triazolyl peaks at 8.39-8.00 clearly depict the formation of the desired glycodendrimer, whereas the peak pattern of the dendron and core can also be seen in the spectra of Figure 3, which substantiate the generation of glycodendrimer 12 .
Apart from this, the disappearance of acetylenic carbon peaks at 78.2, 78.1,76.3, and 76.2 ppm of the core and the appearance of the triazolyl carbon peak in the glycodendrimer 12 NMR support its formation, while the cyclen $\left(-\mathrm{CH}_{2}\right)$ peak of the core at $50.3 \mathrm{ppm}$ can also be seen in ${ }^{13} \mathrm{C}$-NMR of compound 12 , which established the formation of glycodendrimer 12 (Figure 4).

The low polydispersity index $(\mathrm{PDI}=1.11)$ obtained through gel permeation chromatography (GPC) has displayed the thorough molecular structure of the glycodendrimer (Figure 5). We also evaluated the retention time (14.41 $\mathrm{min})$ for glycodendrimer 12 . 


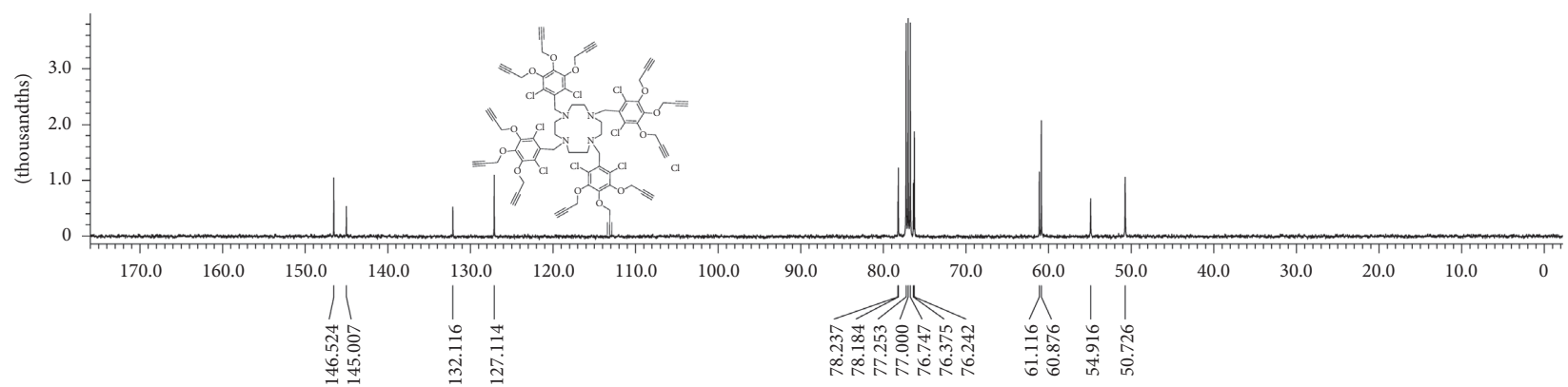

$\mathrm{X}$ : parts per Million : Carbon13

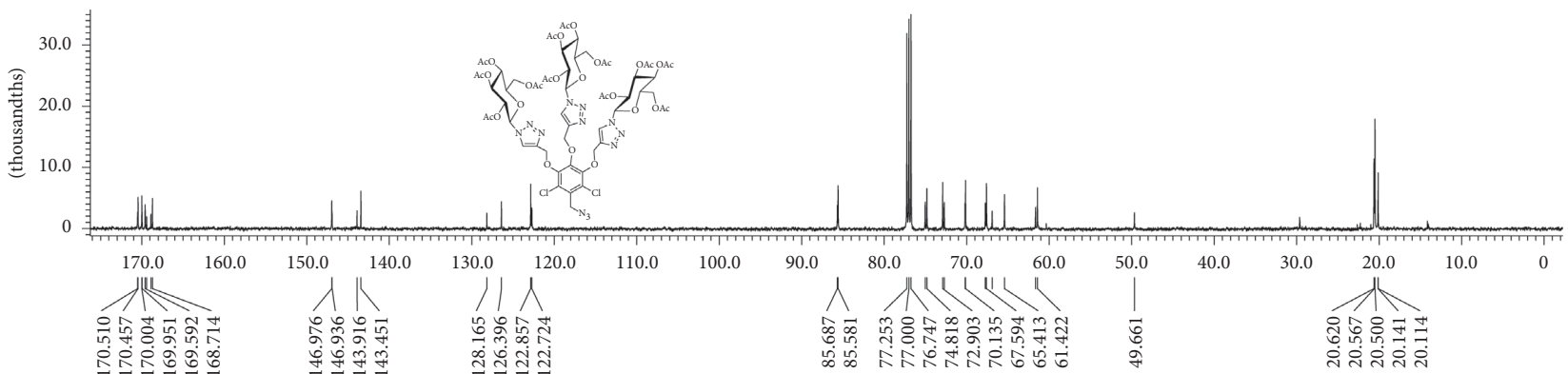

$\mathrm{X}$ : parts per Million : Carbon13

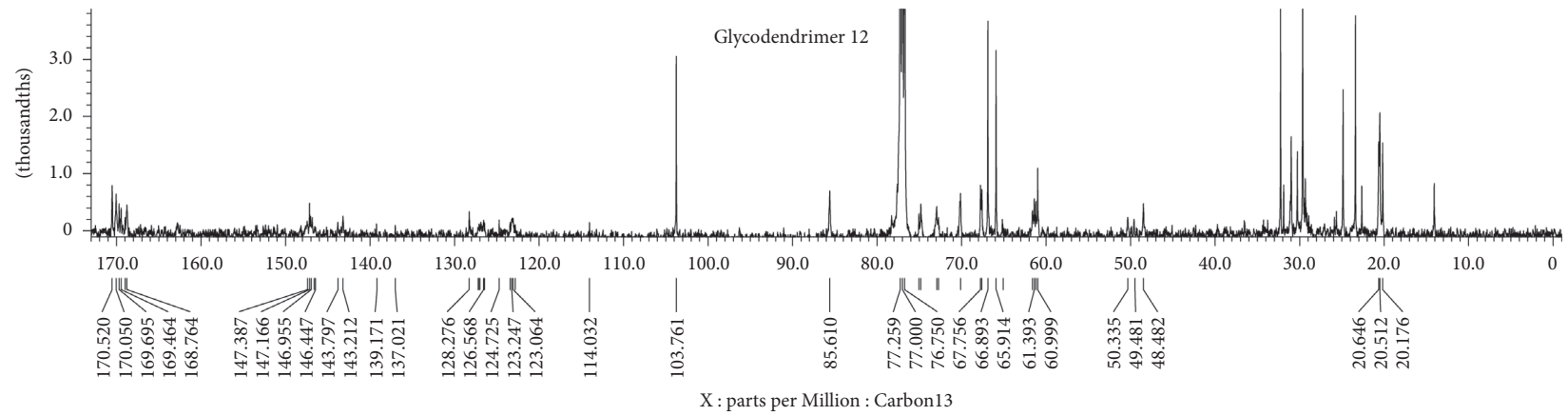

FIgURE 4: ${ }^{13} \mathrm{C}$-NMR spectra of core 7 , dendritic wedge 11 , and chlorine-containing glycodendrimer 12 .

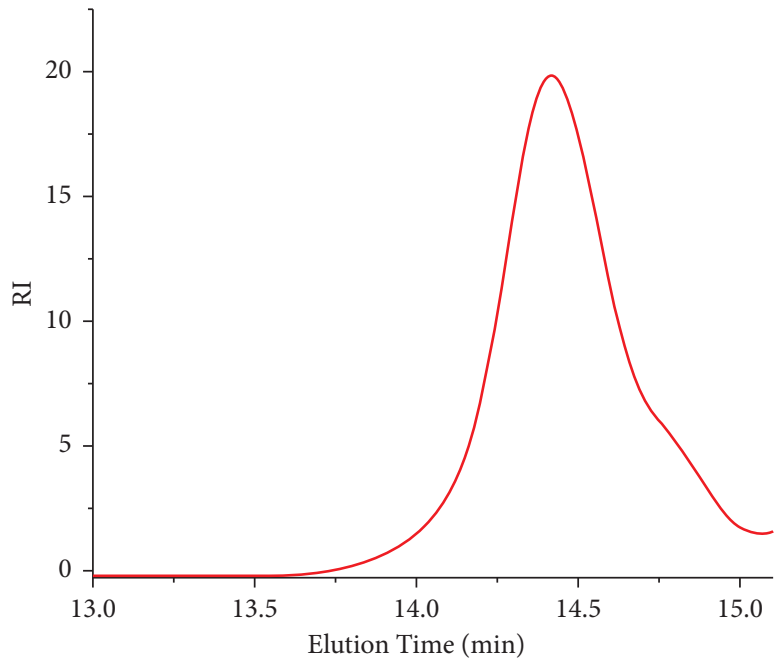

- Glycodendrimer 12

FIGURE 5: SEC diagram of the constructed glycodendrimer 12. 


\section{Conclusion}

The work presented here involved the synthesis of glycodendrimer of high-glucose tethers with low generation using the copper catalyst. In this regard, a hypercore having 12alkynyl functionality derived from the cyclen unit was constructed. Thereafter, glucodendrons were grafted over the hypercore to generate a giant chlorine-containing 36peripheral glucosylated glycodendrimer of $G_{1}$ generation. Furthermore, the constructed glycodendrimers were well characterized by their NMR, HRMS, and IR spectral data. Moreover, the size-exclusion chromatogram has displayed the high monodispersity of the achieved glycodendrimer.

\section{Data Availability}

The data used to support the findings of this study are available from the corresponding author upon request.

\section{Conflicts of Interest}

The authors declare no conflicts of interest.

\section{Authors' Contributions}

AKA synthesized and performed the most of the writing part and prepared the original draft. SK performed the synthesis of starting material. AS performed data analysis. VKT performed data analysis, supervised and analyzed the study, and reviewed and edited the article.

\section{Acknowledgments}

The authors gratefully acknowledge the Council of Scientific and Industrial Research (CSIR), New Delhi (Scheme no. 02(0345)/19/EMR-II), and IoE, Banaras Hindu University (BHU), for the funding. The authors also thank Prof. S. Bhattacharya for his support in the preparation of the catalyst. AKA sincerely acknowledges CSIR, New Delhi, for the Senior Research Fellowship (SRF). The authors sincerely thank CISC-Department of Chemistry, BHU, Varanasi, for providing spectroscopic studies of the developed molecules.

\section{References}

[1] A. K. Agrahari, P. Bose, M. K. Jaiswal et al., "Cu(I)-Catalyzed click chemistry in glycoscience and their diverse applications," Chemical Reviews, vol. 121, no. 13, pp. 7638-7956, 2021.

[2] R. Sharma, I. Zhang, L. Abbassi, R. Rej, D. Maysinger, and R. Roy, "A fast track strategy toward highly functionalized dendrimers with different structural layers: an "onion peel approach"," Polymer Chemistry, vol. 6, no. 9, pp. 1436-1444, 2015.

[3] J. Camponovo, C. Hadad, J. Ruiz et al., "“Click” glycodendrimers containing 27, 81, and 243 modified xylopyranoside termini," Journal of Organic Chemistry, vol. 74, no. 14, pp. 5071-5074, 2009.

[4] R. T. Lee, H.-J. Gabius, and Y. C. Lee, "The sugar-combining area of the galactose-specific toxic lectin of mistletoe extends beyond the terminal sugar residue: compaison with a homologous toxic lectin, ricin," Carbohydrate Research, vol. 254, pp. 269-276, 1994.

[5] C.-H. Wong, Carbohydrate-based Drug Discovery, Wiley VCH, Weinheim, 2003.

[6] S. Horiya, I. S. MacPherson, and I. J. Krauss, "Recent strategies targeting HIV glycans in vaccine design," Nature Chemical Biology, vol. 10, no. 12, pp. 990-999, 2014.

[7] S. H. Medina and M. E. H. El-Sayed, "Dendrimers as carriers for delivery of chemotherapeutic agents," Chemical Reviews, vol. 109, no. 7, pp. 3141-3157, 2009.

[8] M. Gorzkiewicz, I. Jatczak-Pawlik, M. Studzian et al., "Glycodendrimer nanocarriers for direct delivery of fludarabine triphosphate to leukemic cells: improved pharmacokinetics and pharmacodynamics of fludarabine," Biomacromolecules, vol. 19, no. 2, pp. 531-543, 2018.

[9] V. K. Tiwari, Carbohydrates in Drug Discovery and Development, Elsevier, Amsterdam, Netherlands, 2020.

[10] H.-J. Gabius, S. André, J. Jiménez-Barbero, A. Romero, and D. Solís, "From lectin structure to functional glycomics: principles of the sugar code," Trends in Biochemical Sciences, vol. 36, no. 6, pp. 298-313, 2011.

[11] Y. M. Chabre and R. Roy, "Multivalent glycoconjugate syntheses and applications using aromatic scaffolds," Chemical Society Reviews, vol. 42, no. 11, pp. 4657-4708, 2013.

[12] Y. M. Chabre, P. P. Brisebois, L. Abbassi et al., "Hexaphenylbenzene as a rigid template for the straightforward syntheses of "Star-Shaped" glycodendrimers," Journal of Organic Chemistry, vol. 76, no. 2, pp. 724-727, 2011.

[13] D. Zanini and R. Roy, "Novel dendritic $\alpha$-sialosides: synthesis of glycodendrimers based on a 3, 3'-Iminobis (propylamine) core," Journal of Organic Chemistry, vol. 61, no. 21, pp. 7348-7354, 1996.

[14] N. Röckendorf and T. K. Lindhorst, "Glycodendrimers," Dendrimers IV, vol. 217, pp. 201-238, 2001.

[15] A. K. Agrahari, A. S. Singh, A. K. Singh et al., "Click inspired synthesis of hexa and octadecavalent peripheral galactosylated glycodendrimers and their possible therapeutic applications," New Journal of Chemistry, vol. 43, no. 31, pp. 12475-12482, 2019.

[16] D. Kushwaha and V. K. Tiwari, "Click chemistry inspired synthesis of glycoporphyrin dendrimers," Journal of Organic Chemistry, vol. 78, no. 16, pp. 8184-8190, 2013.

[17] A. Rodríguez-Rodríguez, Z. Garda, E. Ruscsák et al., "Stable $\mathrm{Mn}^{2+}, \mathrm{Cu}^{2+}$ and $\mathrm{Ln}^{3+}$ complexes with cyclen-based ligands functionalized with picolinate pendant arms," Dalton Transactions, vol. 44, no. 11, pp. 5017-5031, 2015.

[18] T. J. Wadas, E. H. Wong, G. R. Weisman, and C. J. Anderson, "Coordinating radiometals of copper, gallium, indium, yttrium, and zirconium for PET and SPECT imaging of disease," Chemical Reviews, vol. 110, no. 5, pp. 2858-2902, 2010.

[19] A. J. Counsell, A. T. Jones, M. H. Todd, and P. J. Rutledge, "A direct method for the $N$-tetraalkylation of azamacrocycles," Beilstein Journal of Organic Chemistry, vol. 12, pp. 2457-2461, 2016.

[20] P. Antoni, M. Malkoch, G. Vamvounis et al., "Europium confined cyclen dendrimers with photophysically active triazoles," Journal of Materials Chemistry, vol. 18, no. 22, pp. 2545-2554, 2008.

[21] R. Delgado, V. Félix, L. M. P. Lima, and D. W. Price, "Metal complexes of cyclen and cyclam derivatives useful for medical applications: a discussion based on thermodynamic stability constants and structural data," Dalton Transactions, vol. 26, pp. 2734-2745, 2007. 
[22] M.-G. Baek and R. Roy, "Synthesis and protein binding properties of T-antigen containing GlycoPAMAM dendrimers," Bioorganic \& Medicinal Chemistry, vol. 10, no. 1, pp. 11-17, 2002.

[23] P. I. Kitov, J. M. Sadowska, G. Mulvey et al., "Shiga-like toxins are neutralized by tailored multivalent carbohydrate ligands," Nature, vol. 403, no. 6770, pp. 669-672, 2000.

[24] J. A. F. Joosten, N. T. H. Tholen, F. Ait El Maate et al., "Highyielding microwave-assisted synthesis of triazole-linked glycodendrimers by copper-catalyzed [3 + 2] cycloaddition," European Journal of Organic Chemistry, vol. 2005, no. 15, pp. 3182-3185, 2005.

[25] C. Pifferi, B. Thomas, D. Goyard, N. Berthet, and O. Renaudet, "Heterovalent glycodendrimers as epitope carriers for antitumor synthetic vaccines," Chemistry-A European Journal, vol. 23, no. 64, pp. 16283-16296, 2017.

[26] M. J. Cloninger, "Biological applications of dendrimers," Current Opinion in Chemical Biology, vol. 6, no. 6, pp. 742748, 2002.

[27] V. K. Tiwari, B. B. Mishra, K. B. Mishra, N. Mishra, A. S. Singh, and X. Chen, "Cu-catalyzed click reaction in carbohydrate chemistry," Chemical Reviews, vol. 116, no. 5, pp. 3086-3240, 2016.

[28] F. Vogtle, G. Richardt, and N. Werner, Dendrimer Chemistry: Concept, Synthesis, Properties, Application, Wiley VCH, Weinheim, 2009.

[29] A. K. Agrahari, A. S. Singh, R. Mukherjee, and V. K. Tiwari, "An expeditious click approach towards the synthesis of galactose coated novel glyco-dendrimers and dentromers utilizing a double stage convergent method," RSC Advances, vol. 10, no. 52, pp. 31553-31562, 2020.

[30] P. L. Golas, N. V. Tsarevsky, B. S. Sumerlin, and K. Matyjaszewski, "Catalyst performance in "click" coupling reactions of polymers prepared by ATRP: ligand and metal effects," Macromolecules, vol. 39, no. 19, pp. 6451-6457, 2006.

[31] W.-h. Zhan, H. N. Barnhill, K. Sivakumar, H. Tian, and Q. Wang, "Synthesis of hemicyanine dyes for 'click' bioconjugation," Tetrahedron Letters, vol. 46, no. 10, pp. 1691-1695, 2005.

[32] A. K. Singh, C. L. Yadav, K. B. Mishra et al., "Highly efficient and recyclable pre-catalysts based on mono- and dinuclear heteroleptic $\mathrm{Cu}(\mathrm{I})$ dithio- $\mathrm{PPh} 3$ complexes to produce variety of glycoconjugate triazoles," Molecular Catalysis, vol. 470, pp. 152-163, 2019.

[33] A. Anamika, C. L. Yadav, V. K. Tiwari, M. G. B. Drew, and N. Singh, "Highly efficient structurally characterised novel precatalysts: di- and mononuclear heteroleptic $\mathrm{Cu}(\mathrm{i}) \mathrm{dix}-$ anthate/xanthate-phosphine complexes for azide-alkyne cycloadditions," New Journal of Chemistry, vol. 43, no. 23, pp. 8939-8949, 2019.

[34] K. Kumari, A. S. Singh, K. K. Manar et al., "Catalytic activity of new heteroleptic $[\mathrm{Cu}(\mathrm{PPh} 3) 2(\beta$-oxodithioester) $]$ complexes: click derived triazolyl glycoconjugates," New Journal of Chemistry, vol. 43, no. 3, pp. 1166-1176, 2019.

[35] M. Nayak, D. K. Joshi, K. Kumar, A. S. Singh, V. K. Tiwari, and S. Bhattacharya, "Synthesis of a series of a few hydrosulfide complexes of $\mathrm{Cu}(\mathrm{I})$. A $\mu 3$-SH-bridged rare cubane-like tetramer showing efficient catalytic activity toward azide-alkyne cycloaddition," Inorganic Chemistry, vol. 60, no. 11, pp. 8075-8084, 2021.

[36] N. Sareen, A. S. Singh, V. K. Tiwari, R. Kant, and S. Bhattacharya, "A dinuclear copper(I) thiodiacetate complex as an efficient and reusable 'click' catalyst for the synthesis of glycoconjugates," Dalton Transactions, vol. 46, no. 11, pp. 12705-12710, 2017.

[37] D. Henschler, "Toxicity of chlorinated organic compounds: effects of the introduction of chlorine in organic molecules," Angewandte Chemie International Edition in English, vol. 33, no. 19, pp. 1920-1935, 1994.

[38] B. Hileman, "Chlorine industry groups make moves to ease concerns about their products," Chemical \& Engineering News Archive, vol. 19, no. 22, pp. 11-20, 1993.

[39] G. MuEller, G. Nkusi, and F. SchoEler, "Natural organohalogens in sediments," Journal Fur Praktische Chemie, vol. 338, no. 1, pp. 23-29, 1996.

[40] A. K. Agrahari, M. K. Jaiswal, M. S. Yadav, and V. K. Tiwari, "CuAAC mediated synthesis of cyclen cored glycodendrimer of high sugar tethers at low generation," Carbohydrate Research, vol. 508, Article ID 108403, 2021.

[41] D. Astruc, C. Deraedt, R. Djeda et al., "Dentromers, a family of super dendrimers with specific properties and applications," Molecules, vol. 23, no. 4, pp. 966-980, 2018.

[42] C. Ornelas, "Brief timelapse on dendrimer chemistry: advances, limitations, and expectations," Macromolecular Chemistry and Physics, vol. 217, no. 2, pp. 149-174, 2016.

[43] P. Wu, M. Malkoch, J. N. Hunt et al., "Multivalent, bifunctional dendrimers prepared by click chemistry," Chemical Communications, vol. 46, no. 46, pp. 5775-5777, 2005.

[44] W.-Y. Fang, L. Ravindar, K. P. Rakesh et al., "Synthetic approaches and pharmaceutical applications of chloro-containing molecules for drug discovery: a critical review," European Journal of Medicinal Chemistry, vol. 173, pp. 117153, 2019.

[45] K. P. R. Kartha and R. A. Field, "Iodine: a versatile reagent in carbohydrate chemistry IV. Per-O-acetylation, regioselective acylation and acetolysis," Tetrahedron, vol. 53, no. 34, pp. 11753-11766, 1997. 